\title{
Cystic Fibrosis Transmembrane Conductance Regulator Can Export Hyaluronan
}

\author{
Tobias Schulz $^{\mathrm{a}}$ Udo Schumacher ${ }^{\mathrm{b}}$ Christian Prante ${ }^{\mathrm{d}}$ Wolfgang Sextro ${ }^{c}$ \\ Peter Prehm ${ }^{\mathrm{a}}$ \\ a Münster University Hospital, Institute of Physiological Chemistry and Pathobiochemistry, Münster, \\ bUniversity Medical Centre Hamburg-Eppendorf, Institute for Anatomy II: Experimental Morphology, and \\ ${ }^{c}$ CF Zentrum Altona, Hamburg, and d Institut für Laboratoriums- und Transfusionsmedizin, Herz- und \\ Diabeteszentrum Nordrhein-Westfalen, Universitätsklinik der Ruhr-Universität Bochum, \\ Bad Oeynhausen, Germany
}

\section{Key Words}

$A B C$ transporter $\cdot$ Cystic fibrosis - Cystic fibrosis transmembrane conductance regulator $\cdot$ Extracellular matrix $\cdot$ Hyaluronan

\section{Abstract}

Objectives: Hyaluronan, a major water binding component of the extracellular matrix, is synthesised within the cytosol and exported across the plasma membrane by the ABCtransporter MRP5 in fibroblasts. Although its synthesis is vital for embryogenesis, MRP5-deficient mice are without phenotype, suggesting that another transporter had substituted for the MRP5 protein. Thus, we searched for a compensatory exporter in fibroblasts from MRP5 deficient mice and found that cystic fibrosis transmembrane conductance regulator (CFTR) mRNA was upregulated. Methods: Hyaluronan export was measured in cell culture. The CFTR transporter was knocked out using si-RNA. Blockers of the ABC-transporter family were used to ascertain the hyaluronan transport capabilities functionally. Results: CFTR specific siRNA inhibited hyaluronan export. The tetrasaccharide was exported in undegraded form only from normal human epithelial cells and not from human epithelial cells carrying
$\Delta$ F508 CFTR. The CFTR inhibitors GlyH-101 and CFTR $_{172}$ reduced hyaluronan export from CFTR-expressing mouse fibroblasts and from human breast cancer cell lines. Bronchial secretions from patients with cystic fibrosis that consist mainly of necrotic epithelia contained at least 40 -fold higher concentration of hyaluronan than secretions from patients with acute bronchitis. Conclusions: CFTR transports hyaluronan across the plasma membrane of epithelial cells and this transport mechanism is defective in cystic fibrosis patients.

Copyright ๑ 2010 S. Karger AG, Basel

\section{Introduction}

Cystic fibrosis, the most common severe inherited disorder in Caucasians, is caused by mutations of the cystic fibrosis transmembrane conductance regulator (CFTR) gene which belongs to the $\mathrm{ABC}$ transporter family and functions as a chloride channel at apical surfaces of epithelial cells. In the airways, a defective CFTR protein ultimately leads to chronic pulmonary infection and inflammation responsible for almost all the morbidity and mortality of cystic fibrosis patients. Although chloride

\section{KARGER}

Fax +4161306 1234

E-Mail karger@karger.ch

www.karger.com
(C) 2010 S. Karger AG, Basel

$1015-2008 / 10 / 0774-0200 \$ 26.00 / 0$

Accessible online at:

www.karger.com/pat 
transport has been suggested to be the main function of this channel, doubts about this hypothesis arose when Beck et al. [1] found no correlation between chloride currents and cystic fibrosis phenotype. This doubt was reinforced by the observation that secretions from nasal epithelia of cystic fibrosis mice showed decreased volume rather than abnormal salt concentration [2] and that both cystic fibrosis and normal airway surface liquids are nearly isotonic [3]. However, mucous and liquid secretions are uncoupled in cystic fibrosis patients and this uncoupling leads to a defective clearance of mucus from the gland ducts [4]. Thus, CFTR-mediated liquid secretion is normally necessary for the normal hydration of mucins in submucosal glands. In the absence of a sufficient hydration in cystic fibrosis patients, mucus plaques become adherent to airway surfaces $[5,6]$ and this lack of hydration results in a thick, sticky mucous layer that cannot be removed by cilia and traps bacteria, causing chronic infections.

Hyaluronan is a very large glycosaminoglycan that is exported into the extracellular matrix by both fibroblasts and epithelial cells, where it attracts water, swells accordingly to enormous volumes and displaces other resident macromolecules. Hyaluronan biosynthesis proceeds by alternate transfer of the precursor nucleotide sugars UDP-GlcA and UDP-GlcNac at the inner face of the plasma membrane [7-10]. The growing hyaluronan chain is synthesised within the cytoplasm and exported into the extracellular matrix. The export was originally thought to be performed by the synthase itself in Streptococci [11] as well as in vertebrate cells [12]. However, we discovered that hyaluronan is exported through the protoblast membrane of Streptococci by an ABC transporter [13]. As the streptococcal hyaluronan transporter had structural and functional homology to human multidrug resistance transporters, we investigated potential hyaluronan exporters in human fibroblasts and identified MRP5 as its main transporter across the plasma membrane [14, 15]. Our findings thus showed that two cellular processes are essential for the deposition of hyaluronan in the extracellular matrix: hyaluronan synthesis via the hyaluronan synthase within the cytosol, and hyaluronan export through the plasma membrane via the MRP5 transporter.

Lack of hyaluronan deposition in the extracellular matrix is incompatible with life, as demonstrated by hyaluronan synthase-deficient mice, which die at a stage E9.5 during embryonic development [16]. However, if MRP5 was the sole hyaluronan transporter, it would be expected that MRP5-deficient mice die at about the same intra- uterine age as the hyaluronan synthase deficient mice. As MRP5-deficient mice do not have an obvious phenotype [17] it is likely that they have an alternative hyaluronan exporter from another member of the $\mathrm{ABC}$ transporter family. Members of this large family can compensate each other in the pump function $[18,19]$. We therefore searched for members of the ABC transporter family which could substitute for the MRP5 transporter in fibroblasts of MRP5 deficient mice. We focused on CFTR as this transporter has previously been shown to transport glucuronic acid [20] which is a moiety of hyaluronan.

\section{Materials and Methods}

Sputum was obtained from patients with cystic fibrosis and patients with acute tracheobronchitis. MRP5-deficient mice were provided by Dr. P. Borst, Amsterdam [17]. CFTR and non-sense siRNA were from Ambion (Cambridgeshire, UK); monoclonal antibodies against CFTR were from Acris (Herford, Germany); GlyH-101 (N-(2-Naphthalenyl)-((3,5-dibromo-2,4-dihydroxyphenyl)-methylene)-glycine hydrazide) was from Calbiochem; primers were from MWG Biotech (Ebersberg, Germany); the thiazolidone CFTRact-06 was synthesised as described [21]; other chemicals were from Sigma Chemical.

\section{Cells}

Primary skin fibroblast cultures from wild-type and MRP5deficient mice were established and grown in RPMI supplemented with streptomycin/penicillin (100 units of each/ml) and $10 \%$ foetal calf serum. Human epithelial cells containing wild-type CFTR and mutant, $\Delta$ F508 CFTR were kindly provided by Dr. D.C. Gruenert [22].

\section{General Methods}

Determination of hyaluronan synthase activity [14], and hyaluronan concentration by an ELISA-like assay using the hyaluronan binding protein of aggrecan [14] and knockdown by RNA interference [15] were performed as described. For quantitative RT-PCR we used RT-PCR of CFTR, MRP1-6, MRP8, MDR1 and $\alpha$-actin using the primers in table 1 and the Access RT-PCR System (Promega) and Platinum ${ }^{\circledR} \mathrm{SYBR}^{\circledR}$ Green qPCR SuperMixUDG (Invitrogen) and a Mastercycler ${ }^{\circledR}$ ep realplex (Eppendorf).

\section{Preparation of Fluorescent Hyaluronan and Measurement of} Its Export

Hyaluronan (10 mg) was degraded into oligosaccharides by testicular hyaluronidase $(1 \mathrm{mg} / \mathrm{ml})$ in $10 \mathrm{ml}$ of $0.1 \mathrm{M}$ sodium acetate buffer $\mathrm{pH} 5.2,0.15 \mathrm{M} \mathrm{NaCl}$ for $16 \mathrm{~h}$ at $37^{\circ} \mathrm{C}$, yielding the hyaluronan tetrasaccharide as the main digestion product [23]. The enzyme was inactivated at $100^{\circ} \mathrm{C}$ for $3 \mathrm{~min}$ and precipitated by centrifugation for $3 \mathrm{~min}$ at $14,000 \mathrm{rpm}$. The supernatant was evaporated, and the hyaluronan oligosaccharides were dansylated at the reducing end according to the procedure of Du and Eddington [24]. The residue was dissolved in $100 \mu \mathrm{l}$ of $1 \%$ trichloroacetic acid, $26.5 \mathrm{mg}$ of dansylhydrazine in $200 \mu \mathrm{l}$ of dimethylsulfoxide and the mixture was kept at $60^{\circ} \mathrm{C}$ for $18 \mathrm{~min}$. The fluorescent hy- 
Table 1. Primer and siRNA sequences used

a The primer sequences of CFTR, MRP 1-6, MRP8 and MDR1 for RT-PCR and expected sizes of PCR products

\begin{tabular}{llll}
\hline Gene & Forward primer sequences $\left(5^{\prime}-3^{\prime}\right)$ & Reverse primer sequences $\left(5^{\prime}-3^{\prime}\right)$ & $\begin{array}{l}\text { Product } \\
\text { bp }\end{array}$ \\
\hline B-Actin & CGT GCG TGA CAT CAA AGA GA & TCC TGT CAG CAA TGC CTG GG & 341 \\
MDR1 & GCA ATT TAG TGG AGT CGT GTT C & GCA AGA CTT AGT GGT GCT AG & 640 \\
MRP1 & CTG ATG AAG AAG TCT GGA TGG & GTG AGG GCT TGA AGA GGA AA & 329 \\
MRP2 & TTG GCT CAT CTC AAA TCC TT & ACA ATC TTG CCG CTC TCT AG & 304 \\
MRP3 & CTA TGC CTT ACA GGT GAC CA & GGG ACA ACA TCA GGT ACT AAT & 309 \\
MRP4 & ATG TGG ACC CAA GAA CGG AT & GGC TGT CCA TTG GAG GTG TT & 327 \\
MRP5 & CAT AGC AAG AGC AAG AGC CC & GTG GTA ATC AGG GCA ATG CT & 402 \\
MRP6 & GGA TGA ACC TGG ACC TGC TT & TGC CCC TCA TCC ATG ACT AGG & 463 \\
MRP8 & AGT GAC CTT ACA AGA ATG GAG G & GGC AAT CCA ACA TCG CTT CTA & 403 \\
\hline
\end{tabular}

b CFTR sense and antisense sequences $\left(5^{\prime}-3^{\prime}\right)$ for siRNA; sequences 4 and 5 are mismatch (underlined) siRNA of sequences 2 and 3 , respectively, that were used as controls

\begin{tabular}{|c|c|c|}
\hline No. & Sense & Antisense \\
\hline 1 & GCAGAGUGUUUAAGUUUAUtt & AUAAACUUAAACACUCUGCtc \\
\hline 2 & GCUGAAAAUGACCCGGAAGtt & CUUCCGGGUCAUUUUCAGCtc \\
\hline 4 & GCUGAAA $\underline{G U G G C C C G G A A G t t ~}$ & CUUCCGGGㄷCAㅌUUUCAGCtc \\
\hline 5 & GGCGGCCUGUGGUGAGGUUCtt & GAACCUCA $\underline{C} A \underline{C} A G G C C G C C t t$ \\
\hline
\end{tabular}

aluronan oligosaccharides were purified by gel filtration on a Sephadex G-15 column $(2.4 \times 12 \mathrm{~cm})$ using the pinocytosis medium (Dulbecco's medium containing $1 \mathrm{M}$ sucrose, $10 \%$ polyethylene glycol 600) as eluent. The eluate was monitored by a fluorescent lamp. The first fractions of the void volume were discarded and the highly fluorescent fractions were collected.

Wild-type and mutant $\Delta$ F508 CFTR human epithelial cells (2 $\left.\times 10^{6}\right)$ were seeded in 6 -well plates $\left(9.6 \mathrm{~cm}^{2}\right.$ surface area per well) and grown for $24 \mathrm{~h}$. The medium was withdrawn and the cells were incubated in $1 \mathrm{ml} /$ well of pinocytosis medium containing the fluorescent hyaluronan oligosaccharides for $15 \mathrm{~min}$ at $37^{\circ} \mathrm{C}$ [25]. This procedure has been shown to maintain excellent cell viability $[26,27]$, plating efficiency and minimal damage to the cells [28]. Non-specific effects of the method were confined to transient decrease of protein and DNA synthesis [29]. Further possible non-specific effects have already been excluded in our previous publication [15]. The pinocytosis medium was then replaced with a mixture of Dulbecco's medium/ $\mathrm{H}_{2} \mathrm{O}$ 1:2 (v/v) for 5 min to lyse the pinocytic vesicles. This loading procedure was repeated twice. Cells were incubated in PBS containing $5.6 \mathrm{~mm}$ glucose, $1 \mathrm{mM}$ $\mathrm{MgCl}_{2}$ and $5 \mathrm{mM} \mathrm{KCl}$. After different time periods, the appearance of fluorescence in the supernatant was determined in a fluorimeter with the excitation wavelength at $330 \mathrm{~nm}$ and emission wavelength at $530 \mathrm{~nm}$. The sensitivity of the fluorimeter was calibrated by dansylcadaverine. The fluorescent solution $(2 \mathrm{ml})$ was then lyophylised, the residue was dissolved in $0.1 \mathrm{ml}$ of water and applied to gel filtration on Sephadex-G15 using a Pasteur pipette.
Fractions of $0.2 \mathrm{ml}$ were collected and the fluorescence was determined in a fluorimeter. As a specificity control, we used $1 \mathrm{mg}$ of glucose tetrasaccharide dansylated by the same technique as described above and subjected it to the same export procedure.

\section{Determination of Cell-Associated Hyaluronan}

Fibroblasts were seeded into 24 well plates $\left(1 \mathrm{~cm}^{2}\right.$ surface area per well) and grown to confluency. The medium was replaced with $1 \mathrm{ml}$ of medium containing increasing concentrations of GlyH-101 and $\left[{ }^{3} \mathrm{H}\right]$ glucosamine $(1 \mu \mathrm{Ci} / \mathrm{ml})$ and incubated for $24 \mathrm{~h}$ at $37^{\circ} \mathrm{C}$. The supernatant was discarded, the cells were washed with PBS, lysed directly with $0.1 \%$ SDS or incubated with PBS containing 100 units $/ \mathrm{ml}$ of hyaluronidase for $1 \mathrm{~h}$ and then lysed with $0.1 \%$ of SDS. The lysate was applied to descending paper chromatography in a mixture of $1 \mathrm{M}$ ammonium acetate, $\mathrm{pH}$ 5.5 , and ethanol $(7: 13)$ for $24 \mathrm{~h}$. The origin was excised and the radioactivity was determined. Incorporation of radioactivity into $\left[{ }^{3} \mathrm{H}\right]$ hyaluronan was calculated from the difference in the absence and presence of hyaluronidase.

\section{Determination of Hyaluronan Concentration in Bronchial}

Secretions

The secretions were weighed and dissolved in a 10-fold amount of $4 \mathrm{M}$ guanidinium hydrochloride. Undissolved material was removed by centrifugation at $14,000 \mathrm{~g}$ for $3 \mathrm{~min}$. Aliquots of the supernatant were directly used for determination of the hyaluronan concentration as described [14]. 
Fig. 1. Expression of multidrug-resistant transporters in wild-type and MRP5-deficient mouse fibroblasts. a Qualitative screening of MDR1, MRP1-6, CFTR and MRP8 mRNA of wild-type (wt) and MRP5-deficient mouse fibroblasts (ko). Cellular mRNAs were isolated and the presence of mRNA was determined by RTPCR. b Levels of CFTR expression. mRNAs were isolated from wild-type and MRP5deficient mouse fibroblasts and quantitative real-time PCR was performed with CFTR-specific primers, actin primers as control. Three different samples were analysed for each assay.

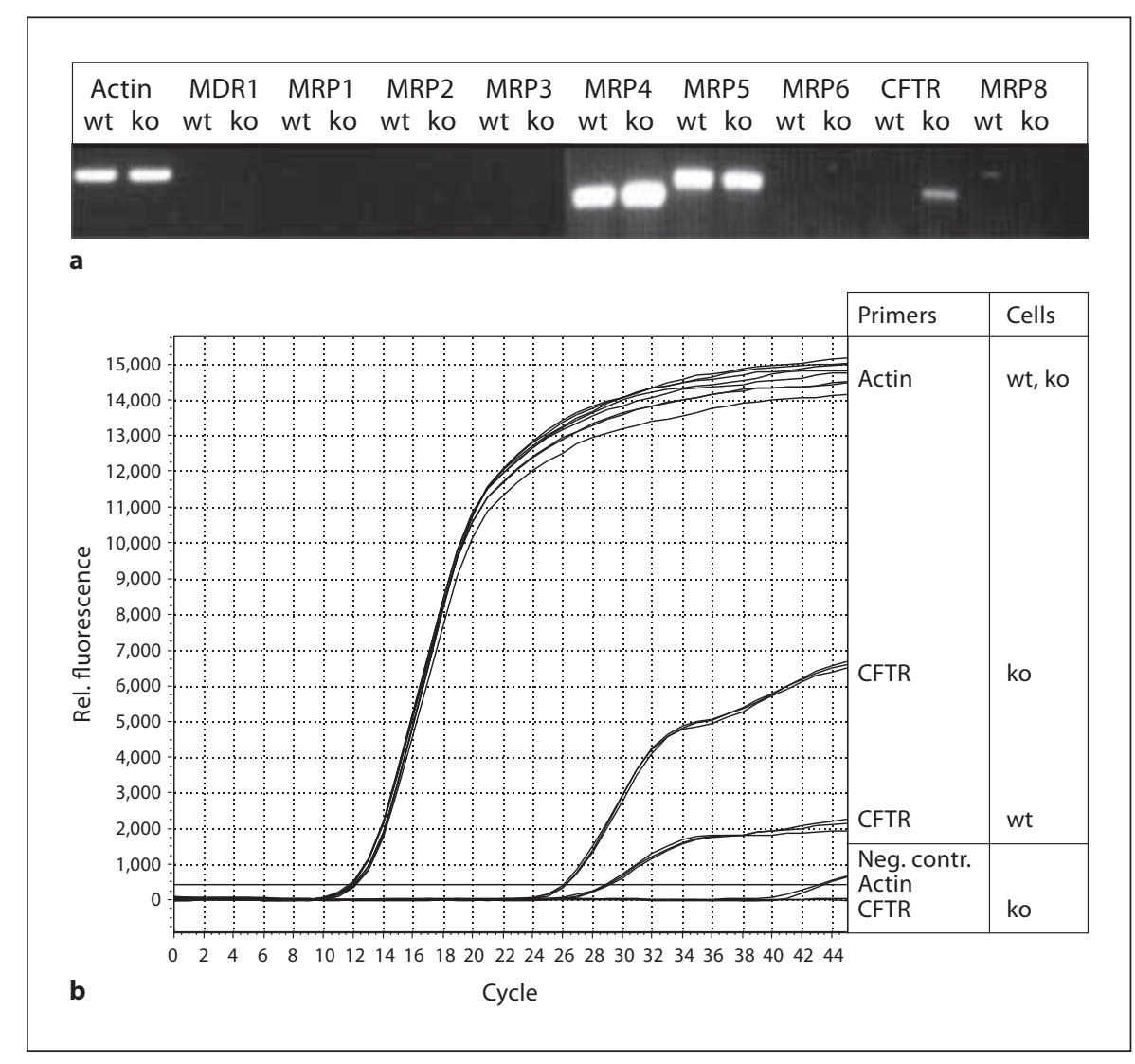

\section{Results}

\section{Identification of the Hyaluronan Exporter in} MRP5-Deficient Mouse Fibroblasts

For the identification of the hyaluronan exporter in MRP5-deficient mouse fibroblasts, we isolated and cultured primary fibroblasts from MRP5-knockout mice [17]. To determine whether the loss of MRP5 caused changes in the expression pattern of other members of the ABC transporters, RT-PCR analyses of MRPs 1-6, CFTR, MRP8 and MDR1 were performed with wild-type and MRP5-deficient fibroblasts. mRNAs were amplified individually using primers specific for each transporter, and the levels of corresponding PCR products were visualised on an agarose gel (fig. 1a). The identity for the PCR products for all the transporters was verified by their molecular size and by nucleotide sequencing. The results showed that the levels of MDR1, MPR1, MRP2, MRP3, MRP6 and MRP8 appeared to be very low or non-detectable. MRP5 appeared unchanged, but no MRP5 protein was detected in Western blots with antibodies against MRP5 confirming previous results [17]. The greatest dif- ference between wild-type and knockout fibroblast was noticed for CFTR. It was virtually absent in wild-type fibroblasts and prominent in MRP5 knockout fibroblasts. A Western blot showed that CFTR was detectable in MRP5-deficient cells, but not in wild-type cells (data not shown).

\section{Inhibition of Hyaluronan Export from}

MRP5-Deficient Mouse Fibroblasts by CFTR-siRNA

To determine the mRNA levels of CFTR in wild-type and MRP5-deficient fibroblasts, we used quantitative RTPCR with CFTR-specific primers (table 1). Figure $1 \mathrm{~b}$ shows that the level of CFTR expression was much higher in MRP5-deficient fibroblasts than in wild-type mouse fibroblasts.

To assess the role of CFTR in hyaluronan export, MRP5-deficient mouse fibroblasts were transfected with three CFTR siRNA in different combinations and nonsense siRNA as control (table 1). Initial experiments indicated that $20 \mathrm{nM}$ of CFTR-specific siRNA was the optimal concentration for reduction of CFTR mRNA. Western blot analysis of whole cell lysates with monoclo- 
nal antibodies against CFTR showed knockdown of the 170-kDa protein with siRNA to different extents (fig. 2a). When the three siRNAs were used individually, only siRNA 3 was effective and this effect was enhanced by combination with siRNA 1 or 2 . In contrast, the combination of siRNA 1 and 2 had no effect. Therefore, the effect of CFTR knockdown was measured with the mixtures of siRNA $2+3$ and $1+3$. Figure $2 b$ shows that hyaluronan export was slightly reduced by siRNA3 and significantly reduced by the combined application of siRNA $1+3$ or $2+3$, as compared with non-sense siRNA. In control experiments, we analysed CFTR siRNA on wild-type cells as well as unrelated siRNA in MRP5-deficient cells and did not find any effects (data not shown). As an additional control, we performed control experiments with mismatch siRNAs 4 and 5 which showed that hyaluronan secretion was not affected. As a further control, we analysed the stability of hyaluronan in the culture supernatant and found that in was not degraded (data not shown), indicating that the effects measured depended solely on hyaluronan acid secretion and not degradation. These siRNAs did not reduce the CFTR message, the protein expression and hyaluronan export (data not shown). This indicated that CFTR exported hyaluronan in MRP5-deficient mouse fibroblasts over-expressing CFTR. To analyse, whether the replacement of MRP5 by CFTR has any effect on the expression or activity of the hyaluronan synthase, we isolated membranes from wild-type and knockout fibroblasts and found that the specific activity of the synthase was not altered. The membrane fractions isolated from $5 \times 10^{7}$ wild-type or MRP5-deficient fibroblasts incorporated 39,945 cpm \pm $3,478 \mathrm{cpm}$ or $39,691 \mathrm{cpm} \pm 844 \mathrm{cpm}$ from UDP- $\left[{ }^{14} \mathrm{C}\right]$ GlcA within $3 \mathrm{~h}$ at $37^{\circ} \mathrm{C}$ into $\left[{ }^{14} \mathrm{C}\right]$ hyaluronan, respectively.

\section{Effect of CFTR Inhibition and Activation on \\ Hyaluronan Export}

If hyaluronan was exported from MRP5-deficient fibroblasts by CFTR, the inhibitory profile should change between normal fibroblasts and MRP5-deficient fibroblasts. Therefore we compared the inhibitory profiles of GlyH-101, a CFTR-specific inhibitor of chloride export [30], on hyaluronan export from wild-type and MRP5deficient mouse fibroblasts. Figure 3a shows that GlyH101 inhibited hyaluronan export from MRP5-deficient fibroblasts at concentrations between 1.5 and $25 \mu \mathrm{M}$ more effectively than from wild-type fibroblasts. It appeared that GlyH-101 could specifically differentiate between the export of hyaluronan by MRP 5 and by CFTR. At con-

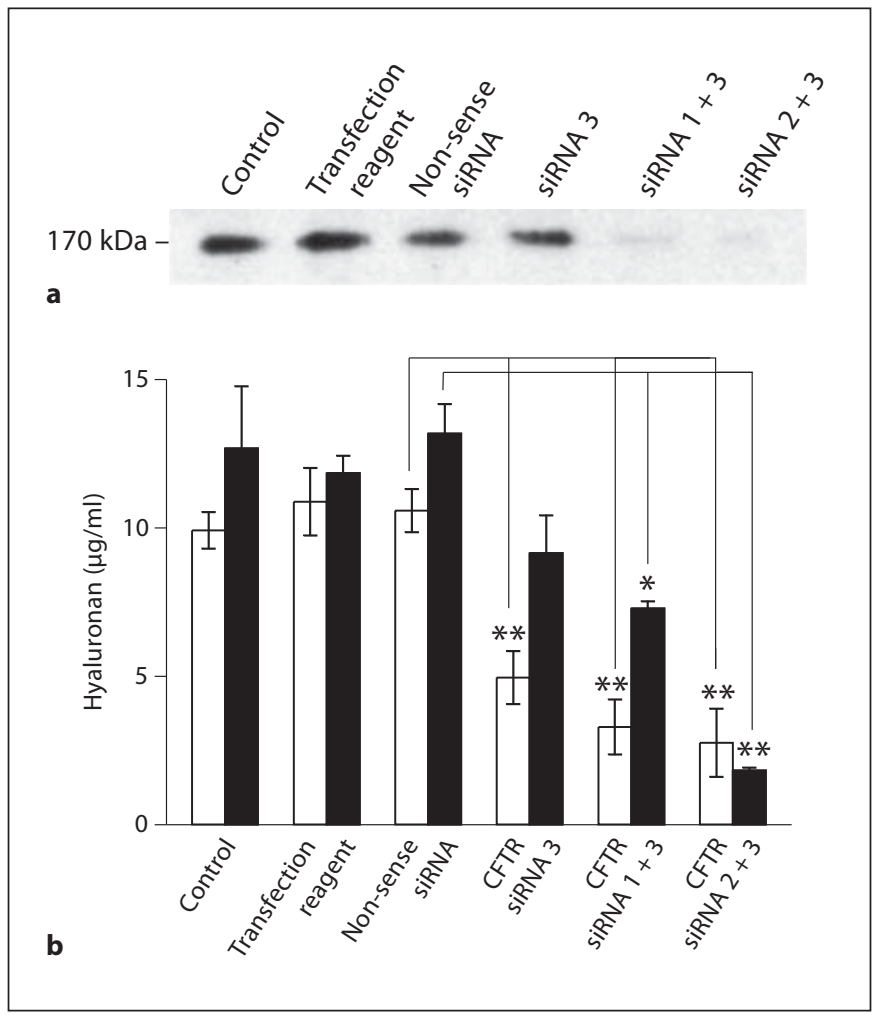

Fig. 2. Inhibition of hyaluronan export by CFTR-siRNA in MRP5deficient mouse fibroblasts. Fibroblasts were seeded in a 12 -well plate and incubated overnight. Cells at $50-60 \%$ confluence were transfected with a mixture of the siRNAs, as compared with a non-sense siRNA. a Specific inhibition of protein expression. The relative intensities of the CFTR protein at $170 \mathrm{kDa}$ were determined by Western blotting with a CFTR-specific monoclonal antibody. $\mathbf{b}$ Inhibition of hyaluronan export. The supernatants were withdrawn after $48 \mathrm{~h}$ (open bars) and $72 \mathrm{~h}$ (solid bars) for determination of hyaluronan concentration. The error bars indicate the SD of 3 experiments. For comparison, the amount of hyaluronan produced by wild-type cells was $9 \mu \mathrm{g} / \mathrm{ml}$ after $48 \mathrm{~h}$, and 13 $\mu \mathrm{g} / \mathrm{ml}$ after $72 \mathrm{~h}$. The mixtures of CFTR siRNA $1+3$ or $2+3$ significantly reduced hyaluronan export. ${ }^{*} \mathrm{p}<0.02$, ${ }^{* *} \mathrm{p}<0.002$ (ANOVA test).

centrations above $50 \mu \mathrm{M}$, it abolished hyaluronan export from both cell lines and it is possible that it exerted nonspecific side effects. As a verification of this hypothesis we compared the accumulation of intracellular hyaluronan in the cell lines. Figure $3 \mathrm{~b}$ shows that intracellular hyaluronan accumulated in MRP5-deficient fibroblasts with increasing concentrations of GlyH-101, but not in wild-type fibroblasts. At a low-medium concentration of GlyH-101, where extracellular hyaluronan acid was reduced, there was no corresponding significant increase observed in the intracellular fraction. In a control exper- 

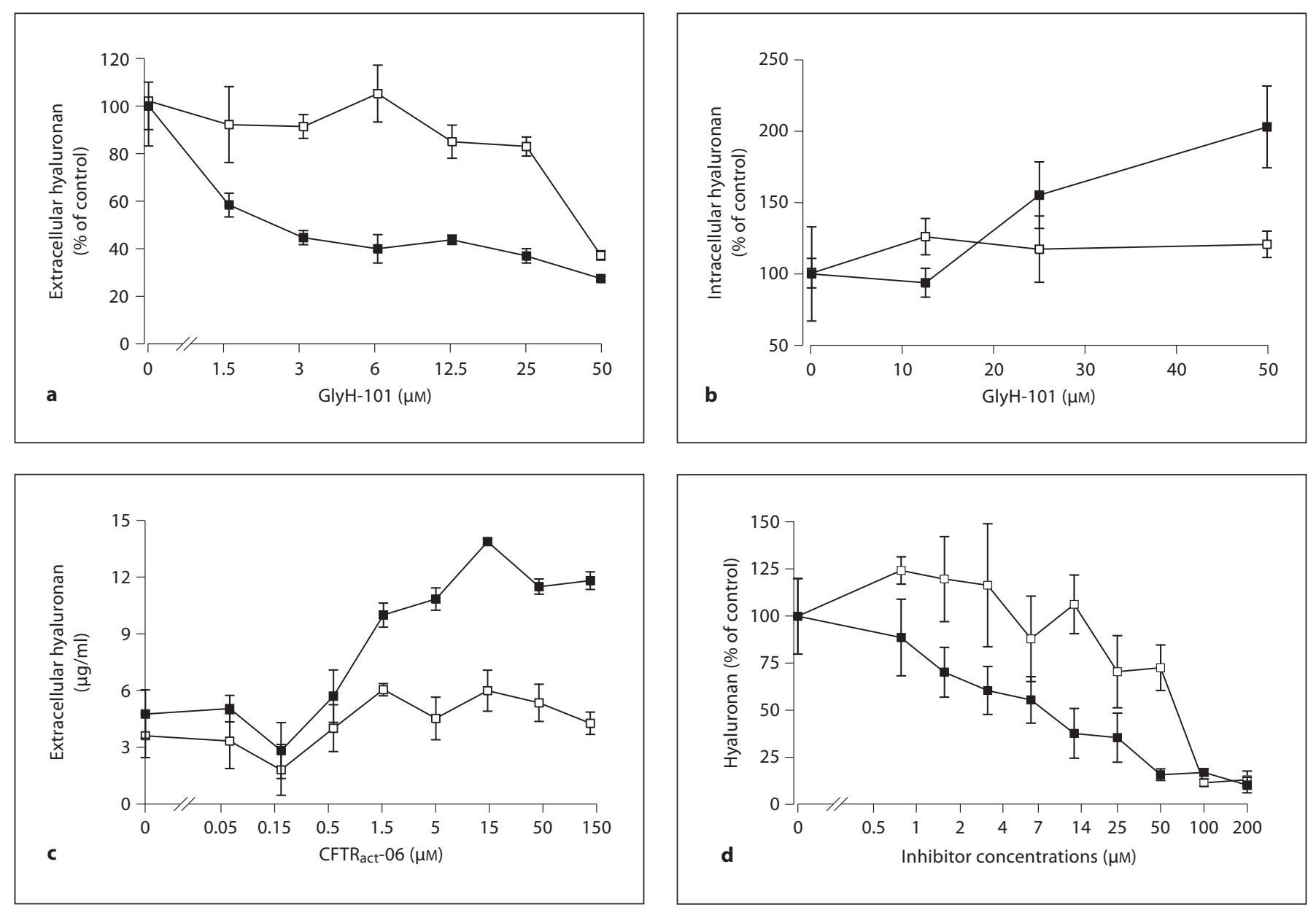

Fig. 3. Inhibition and activation of hyaluronan export. Equal numbers of wild-type ( $\square$ ) and MRP5-deficient ( $\square$ ) mouse fibroblasts were cultured with increasing concentrations of GlyH-101, a specific inhibitor of chloride export by CFTR, for $24 \mathrm{~h}$. The media were replaced with fresh media containing identical GlyH-101 concentrations, and after an additional $24 \mathrm{~h}$ of incubation the amount of extracellular (a) and intracellular (b) hyaluronan was determined and plotted as the SD of 3 measurements. The $100 \%$ values for $\left[{ }^{3} \mathrm{H}\right]$ hyaluronan for $10^{6}$ wild-type cells corresponded to $2.3 \times 10^{6} \mathrm{dpm}$ for the extracellular and $3.6 \times 10^{5} \mathrm{dpm}$ for the intracellular compartment, and for $10^{6}$ MRP5-deficient cells to

$1.9 \times 10^{6} \mathrm{dpm}$ for the extracellular and $4.2 \times 10^{4} \mathrm{dpm}$ for the intracellular compartment. Hyaluronan export was also tested with increasing concentrations of CFTR $\mathrm{act}^{-} 06$ (c), an activator of chloride export, and the amount of extracellular hyaluronan was determined as in figure $2 \mathrm{~b}$ and plotted as the SD of 4 measurements. Hyaluronan export was also inhibited from the breast cancer carcinoma cell line HMT3552 by increasing concentrations of GlyH-101 ( $\square$ ) or $\mathrm{CFTR}_{172}(\boldsymbol{\square})(\mathbf{d})$. The results were normalised to the control without inhibitors containing $2 \mu \mathrm{g} / \mathrm{ml}$ of hyaluronan in the culture medium. The error bars indicate the SD of 3 determinations.

iment, we found that GlyH-101 had no effect on the hyaluronan synthase activity as measured on an isolated membrane preparation (data not shown).

In addition, we also analysed the effect of $\mathrm{CFTR}_{\text {act }}-06$, a specific CFTR activator that greatly prolongs the channel open state [31, 32], on hyaluronan export. Figure 3c shows that $\mathrm{CFTR}_{\mathrm{act}}{ }^{-06}$ stimulated hyaluronan export only from MRP5-deficient fibroblasts, but not in wildtype fibroblasts.

It would be desirable to analyse the effects of the CFTR inhibitors on hyaluronan export from natural epithelial cells directly. Unfortunately, the cell lines did not express hyaluronan synthase. Therefore we used breast cancer carcinoma cell lines that express CFTR [33] and produce hyaluronan [34]. Figure 3d shows that both CFTR inhibitors $\mathrm{GlyH}-101$ and $\mathrm{CFTR}_{175}$ reduced hyaluronan export from HMT3552 cells in a concentration-dependent manner. Similar inhibitions were found for other cell lines. 


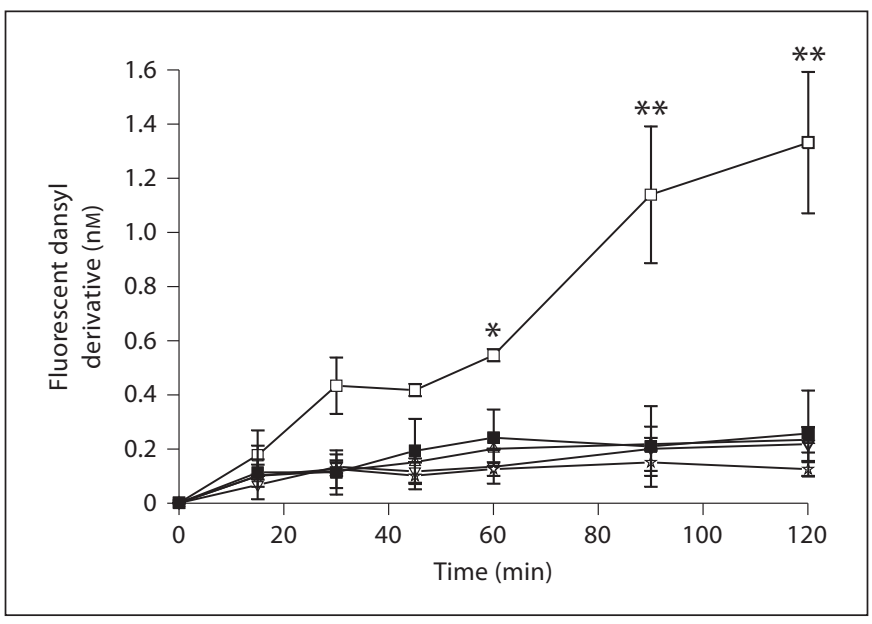

Fig. 4. Export of fluorescent hyaluronan oligosaccharides. Normal human epithelial cells ( $\square$ ) and human epithelial cells carrying $\Delta$ F508 CFTR ( $\square$ ) were loaded with dansylated hyaluronan oligosaccharides by osmotic lysis of pinocytotic vesicles and the export was measured by fluorescence in the culture supernatant at the incubation periods indicated. As further controls, normal human epithelial cells were loaded with dansylated glucose tetrasaccharide containing $\alpha 1-4$ linakges $(\triangle)$, with dansylcadaverin $(\nabla)$, or with dansylated hyaluronan oligosaccharides in the presence of the CFTR inhibitor GlyH-101 ( $\star$ ). The error bars indicate the SD of 3 experiments. ${ }^{*} \mathrm{p}<0.2,{ }^{* *} \mathrm{p}<0.01$ (ANOVA test).

\section{Export of Fluorescent Hyaluronan Oligosaccharides from Human Epithelial Cells}

It would be desirable to measure the export of hyaluronan by CFTR in reconstituted vesicles in order to eliminate any possible intracellular metabolic interference. However, this approach was unsuccessful, probably due to the lack of intracellular hyaluronan-binding proteins. We therefore compared the export of fluorescent hyaluronan oligosaccharides introduced into the cytosol by osmotic lysis of pinocytotic vesicles from normal human epithelial cells and human epithelial cells carrying mutated $\Delta$ F508 CFTR. These cell lines differ only in the presence or absence of F508, rendering CFTR functionally inactive. These cells did not express MRP5 in a Western blot (data not shown). The appearance of fluorescence in the culture supernatant was measured after different incubation periods. Figure 4 shows that only native human epithelial cells with intact CFTR, but not the functionally inactive $\Delta$ F508 CFTR cells, exported hyaluronan oligosaccharides. The exported dansylated product was analysed by gel filtration on Sephadex-G15 and showed an identical elution position as the original dansylated hyaluronan tetrasaccharide, indicating that no intracellular degradation had occurred. As a control for the ef-
Table 2. Analysis of hyaluronan from bronchial secretions of patients with cystic fibrosis and patients with bronchitis

\begin{tabular}{lcll}
\hline & $\begin{array}{l}\mu \text { g hyaluronan/ } \\
\text { g secretion }\end{array}$ & $\begin{array}{l}\text { mg protein/ } \\
\text { g secretion }\end{array}$ & $\begin{array}{l}\mu \text { g hyaluronan/ } \\
\text { mg protein }\end{array}$ \\
\hline $\begin{array}{lll}\text { Acute bronchitis patients } \\
1\end{array}$ & & \\
2 & $0.20 \pm 0.04$ & $0.29 \pm 0.04$ & 0.70 \\
3 & $0.05 \pm 0.02$ & $0.16 \pm 0.03$ & 0.31 \\
4 & $0.07 \pm 0.02$ & $0.32 \pm 0.02$ & 0.22 \\
5 & $0.03 \pm 0.01$ & $0.08 \pm 0.01$ & 0.37 \\
6 & $0.02 \pm 0.01$ & $0.15 \pm 0.02$ & 0.13 \\
7 & $0.03 \pm 0.01$ & $0.14 \pm 0.01$ & 0.22 \\
& $0.32 \pm 0.02$ & $0.38 \pm 0.02$ & 0.84 \\
Cystic fibrosis patients & & \\
CF 772 & $188 \pm 9.5$ & $2.44 \pm 0.11$ & 77 \\
CF 785 & $784 \pm 10.9$ & $3.95 \pm 0.01$ & 198 \\
CF 789 & $638 \pm 54.1$ & $5.31 \pm 0.98$ & 120 \\
CF 791 & $710 \pm 35.8$ & $8.76 \pm 0.47$ & 81 \\
CF 792 & $384 \pm 26.1$ & $2.31 \pm 0.23$ & 166 \\
CF 798 & $124 \pm 16.9$ & $3.54 \pm 0.17$ & 35 \\
\hline
\end{tabular}

Data are means $\pm S D$ of 3 measurements.

fectiveness of the procedure, we introduced dansylcadaverin into the cytosol. Its fluorescence could easily be detected in the cells, but it did not appear in the culture supernatant. As a further specificity control, we performed the experiment with dansylated glucose tetrasaccharide and could not detect any fluorescence in the culture supernatant indicating that export was hyaluronan specific.

\section{Hyaluronan Content in Bronchial Secretions}

The hyaluronan concentrations were determined in bronchial secretions from 6 patients with cystic fibrosis and 7 patients with bronchitis. It could only be detected in the thick mucous from cystic fibrosis patients after dissociation with $4 \mathrm{M}$ guanidinium hydrochloride. The data were related to weight as well as to protein concentrations. Table 2 shows that the hyaluronan concentrations in cystic fibrosis patients ranged from $124-788 \mu \mathrm{g} / \mathrm{g}$ of secretions or $35-198 \mu \mathrm{g} / \mathrm{mg}$ of protein as compared to secretions of bronchitis patients with $0.02-0.32 \mu \mathrm{g} / \mathrm{g}$ of secretions or $0.13-0.84 \mu \mathrm{g} / \mathrm{mg}$ of protein. Thus the ratios of hyaluronan to protein concentrations were at least 40 fold higher in all cystic fibrosis patients. 


\section{Discussion}

Transmembrane transporters of the ATP-binding cassette gene family are the largest family of transport proteins. As these transporters have evolved from a common ancestor gene, a considerable degree of molecular redundancy concerning the transport capabilities are to be expected. Here we were able to demonstrate that the primary hyaluronan exporter MRP5 is readily replaced by a secondary hyaluronan exporter, namely CFTR, in MRP5deficient mice.

The hyaluronan transport function of CFTR was ascertained using different methods and experimental approaches. First, quantitative RT-PCR revealed that the expression of the CFTR mRNA was up-regulated in fibroblasts from MRP5-deficient mice (fig. 1a). To show that CFTR expression was indeed related to hyaluronan export, we used CFTR-specific siRNA. Fibroblasts derived from MRP5-deficient mice transfected with CFTR-specific siRNA showed a decrease in hyaluronan deposition in the extracellular matrix as compared to the non-sense siRNA control (fig. 2b). As functional MRP5 is not available as a hyaluronan transporter in MRP5-knockout mice, our results indicated that the upregulated CFTR compensates MRP5 for hyaluronan export in MRP5-deficient mice. The inhibition of hyaluronan export by GlyH-101 and activation by CFTR act $^{-06}$, an inhibitor and activator of CFTR, respectively, for chloride transport, further supports our hypothesis (fig. 3). Since normal epithelial cell lines did not produce any hyaluronan in cell culture, we wanted to expand our hypothesis that CFTR exports hyaluronan on epithelial cells that produce hyaluronan on their own. We analysed breast cancer cell lines that originate from epithelia, express CFTR [33] and produce hyaluronan [35] and found that both CFTR inhibitors GlyH-101 and CFTR $_{172}$ reduced hyaluronan export. Our result that CFTR exports hyaluronan corroborates recent data that failed to detect MRP4 or MRP5 as principle hyaluronan exporters in breast cancer cells [34]. This result is of interest for two reasons. First, it indicates that a tissue-specific hyaluronan transport exists: mesenchymal cells including fibroblasts use MRP5 as the principle hyaluronan transporter, while epithelia use CFTR as the principle hyaluronan transporter. Second, it is interesting to note that a defect in CFTR inhibits breast cancer cell growth [36] and that silencing to the hyaluronan synthase suppresses the invasiveness of breast cancer cells [37]. Our finding would therefore combine these hitherto unlinked observations as both hyaluronan synthesis catalysed by hyaluronan synthase and its export by ABC- transporter are necessary to result in a deposition of hyaluronan in the extracellular matrix. Impairment of both mechanisms results in reduced growth of breast cancer.

$\mathrm{GlyH}-101$ is known to clog CFTR from outside and thus cannot influence intracellular metabolism [30]. The observation that GlyH-101 inhibited the accumulation of intracellular hyaluronan more than of extracellular hyaluronan could be explained by a feedback inhibition of the hyaluronan chains on their own elongation that we described previously [38]. The inhibitory constant $\mathrm{K}_{\mathrm{i}}$ for chloride export was $1.4 \mu \mathrm{M}$ [30], and thus is in the same concentration range as for the inhibition of hyaluronan export (fig. 3a). In addition, fluorescent hyaluronan oligosaccharides were only exported from human epithelial cells with intact CFTR, but not from mutated $\Delta$ F508 CFTR cells.

At first glance, it is surprising that such diverse substrates as chloride and hyaluronan are exported by the same protein, even though $\mathrm{ABC}$ transporters have notoriously promiscuous properties. However, since CFTR also exports glucuronic acid, one of the two monosaccharide components of hyaluronan disaccharide units [39], comparison of protein sequences of the $\mathrm{ABC}$ transporter family revealed that CFTR is one of the closest relatives to MRP5 [14], further underpinning the common properties of the two proteins. Thus, we conclude that CFTR is not only responsible for chloride, but more importantly for hyaluronan export. This fact has important consequences for the understanding of CFTR in the pathophysiology of cystic fibrosis.

Hyaluronan plays a major role in mucosal defence because it increases the ciliary beat frequency of tracheal epithelial cells $[40,41]$. It is a constituent of human airway secretions and is produced mostly by ciliated surface epithelial cells, with some contributed by submucosal glands [42-44]. In these inflammatory diseases, hyaluronan is exported from serous, but not mucous cells, of human nasal and tracheobronchial submucosal glands only after parasympathetic stimulation [45]. This observation corroborates the finding that CFTR is primarily expressed on the apical surface of serous cells in bronchial submucosal glands and on ciliated cell on the epithelial surface [46-48]. Interestingly, it has also been observed that CFTR gene transfer corrects for defective secretion of unspecified glycoconjugates from tracheal epithelial cells of patients with cystic fibrosis [49].

Hitherto, the hyaluronan concentrations in sputum have only been analysed from healthy subjects, asthma and rhinitis patients [50], and chronic obstructive pulmonary airway disease patients [51]. The analysis of lung secretions from patients with cystic fibrosis revealed that 
hyaluronan was the only glycosaminoglycan found in detectable amounts [52]. We analysed for the first time the hyaluronan concentrations in bronchial secretions from patients with cystic fibrosis and compared it with secretions from patients with acute bronchitis. Bronchitis sputum contained similar amounts of hyaluronan as other inflammatory tracheal diseases. However, the hyaluronan concentrations in cystic fibrosis sputum ranged from 124 to $784 \mu \mathrm{g} / \mathrm{g}$ and were thus more than 100-fold higher than in acute bronchitis. The high hyaluronan concentrations were also reflected in the hyaluronan to protein ratio. Hyaluronan could only be detected after solubilisation under dissociative conditions with $4 \mathrm{M}$ guanidinium hydrochloride. At first sight, our results that defective hyaluronan export leads to higher hyaluronan concentrations in cystic fibrosis sputum seem counter-intuitive as one would expect lower levels. However, the cystic fibrosis sputum mainly consists of cellular debris from necrotic epithelia. Major components of cystic fibrosis sputum are DNA and actin filaments originating from necrosis of epithelial cells $[53,54]$ that have an increased cell death rate [55] and a more than 85 -fold higher proliferation rate than normal epithelium [56]. The intracellular accumulation of hyaluronan in F508 epithelial cells may lead to swelling and oncosis that is caused by defective anion channels [57]. We assume that hyaluronan in sputum from cystic fibrosis patients is associated with intracellular proteins which prevent full hydration. This lack of hydration results in the typical thick mucous seen in cystic fibrosis patients. Our results may be a compromise in the controversy of the cystic fibrosis pathology between the hydration and the salt hypothesis [58], because hyaluronan fulfils both properties being an extremely hydrated salt. Aggregation of hyaluronan with binding proteins has been suggested to be a reaction that accompanies inflammation [59].

\section{Acknowledgments}

The authors thank Dr. S. Misra and Prof. Dr. J.E. Scott for critical reading of the manuscript, and A. Blanke, R. Gehrke, U. Rasmussen, K. Siebert, and R. Schulz for excellent technical assistance. This work was supported by the Deutsche Forschungsgemeinschaft (SFB 492).

\section{References}

1 Beck S, Kuhr J, Schutz VV, Seydewitz HH, Brandis M, Greger R, Kunzelmann K: Lack of correlation between CFTR expression, CFTR $\mathrm{Cl}^{-}$currents, amiloride-sensitive $\mathrm{Na}^{+}$ conductance, and cystic fibrosis phenotype. Pediatr Pulmonol 1999;27:251-259.

2 Caldwell RA, Grubb BR, Tarran R, Boucher RC, Knowles MR, Barker PM: In vivo airway surface liquid Cl- analysis with solid-state electrodes. J Gen Physiol 2002;119:3-14.

-3 Matsui H, Grubb BR, Tarran R, Randell SH, Gatzy JT, Davis CW, Boucher RC: Evidence for periciliary liquid layer depletion, not abnormal ion composition, in the pathogenesis of cystic fibrosis airways disease. Cell 1998; 95:1005-1015.

4 Inglis SK, Wilson SM: Cystic fibrosis and airway submucosal glands. Pediatr Pulmonol 2005;40:279-284.

5 Trout L, Townsley MI, Bowden AL, Ballard ST: Disruptive effects of anion secretion inhibitors on airway mucus morphology in isolated perfused pig lung. J Physiol 2003;549: 845-853.

6 Matsui H, Wagner VE, Hill DB, Schwab UE, Rogers TD, Button B, Taylor RM, Superfine $\mathrm{R}$, Rubinstein M, Iglewski BH, Boucher RC: A physical linkage between cystic fibrosis airway surface dehydration and Pseudomonas aeruginosa biofilms. Proc Natl Acad Sci USA 2006;103:18131-18136.
Prehm P: Synthesis of hyaluronate in differentiated teratocarcinoma cells: mechanism of chain growth. Biochem J 1983;211:191198.

8 Prehm P: Synthesis of hyaluronate in differentiated teratocarcinoma cells: characterization of the synthase. Biochem J 1983;211:181189.

$\checkmark 9$ Prehm P: Hyaluronate is synthesized at plasma membranes. Biochem J 1984;220:597600.

10 Prehm P: Biosynthesis of hyaluronan: direction of chain elongation. Biochem J 2006; 398:469-473.

11 Tlapak-Simmons VL, Kempner ES, Baggenstoss BA, Weigel PH: The active streptococcal hyaluronan synthases (HASs) contain a single HAS monomer and multiple cardiolipin molecules. J Biol Chem 1998;273: 26100-26109.

12 Pummill PE, Kempner ES, DeAngelis PL: Functional molecular mass of a vertebrate hyaluronan synthase as determined by radiation inactivation analysis. J Biol Chem 2001; 276:39832-39835.

13 Ouskova G, Spellerberg B, Prehm P: Hyaluronan release from Streptococcus pyogenes: export by an $\mathrm{ABC}$ transporter. Glycobiology 2004;14:931-938.
14 Prehm P, Schumacher U: Inhibition of hyaluronan export from human fibroblasts by inhibitors of multidrug resistance transporters. Biochem Pharmacol 2004;68:1401-1410.

15 Schulz T, Schumacher U, Prehm P: Hyaluronan export by the ABC-transporter MRP5 and its modulation by intracellular cGMP. J Biol Chem 2007;282:20999-21004.

16 Camenisch TD, Spicer AP, Brehm-Gibson T, Biesterfeldt J, Augustine ML, Calabro A Jr, Kubalak S, Klewer SE, McDonald JA: Disruption of hyaluronan synthase-2 abrogates normal cardiac morphogenesis and hyaluronan-mediated transformation of epithelium to mesenchyme. J Clin Invest 2000;106:349360.

17 de Wolf CJ, Yamaguchi H, Van der Heijden I, Wielinga PR, Hundscheid SL, Ono N, Scheffer GL, de Haas M, Schuetz JD, Wijnholds J, Borst P: cGMP transport by vesicles from human and mouse erythrocytes. FEBS J 2007;274:439-450.

18 Schinkel AH, Smit JJ, van Tellingen O, Beijnen JH, Wagenaar E, van Deemter L, Mol CA, van der Valk MA, Robanus-Maandag EC, te Riele HP: Disruption of the mouse mdrla P-glycoprotein gene leads to a deficiency in the blood-brain barrier and to increased sensitivity to drugs. Cell 1994;77: 491-502. 
19 Hirohashi T, Suzuki H, Ito K, Ogawa K, Kume K, Shimizu T, Sugiyama Y: Hepatic expression of multidrug resistance-associated protein-like proteins maintained in eisai hyperbilirubinemic rats. Mol Pharmacol 1998; 53:1068-1075.

20 Linsdell P, Hanrahan JW: Substrates of multidrug resistance-associated proteins block the cystic fibrosis transmembrane conductance regulator chloride channel. Br J Pharmacol 1999;126:1471-1477.

-21 Lesyk R, Zimenkovsky B, Subtelna I, Nektegayev I, Kazmirchuk G: Synthesis and antiinflammatory activity of some 2-arylamino2-thiazoline-4-ones. Acta Pol Pharm 2003; 60:457-466.

-22 Kunzelmann K, Schwiebert EM, Zeitlin PL, Kuo WL, Stanton BA, Gruenert DC: An immortalized cystic fibrosis tracheal epithelial cell line homozygous for the delta F508 CFTR mutation. Am J Respir Cell Mol Biol 1993;8:522-529.

23 Gorham SD, Olavesen AH, Dodgson KS: Effect of ionic strength and $\mathrm{pH}$ on the properties of purified bovine testicular hyaluronidase. Connect Tissue Res 1975;3:17-25.

-24 Du J, Eddington N: Determination of the chondroitin sulfate disaccharides in dog and horse plasma by HPLC using chondroitinase digestion, precolumn derivatization, and fluorescence detection. Anal Biochem 2002; 306:252-258.

- 25 Okada CY, Rechsteiner M: Introduction of macromolecules into cultured mammalian cells by osmotic lysis of pinocytic vesicles. Cell 1982;29:33-41.

26 Rechsteiner M: Osmotic lysis of pinosomes. Methods Enzymol 1987;149:42-48.

$\checkmark 27$ Lee G, Delohery TM, Ronai Z, Brandt-Rauf PW, Pincus MR, Murphy RB, Weinstein IB: A comparison of techniques for introducing macromolecules into living cells. Cytometry 1993; 14:265-270.

28 Ghosh C, Iversen PL: Intracellular delivery strategies for antisense phosphorodiamidate morpholino oligomers. Antisense Nucleic Acid Drug Dev 2000;10:263-274.

-29 Chakrabarti R, Pfeiffer NE, Wylie DE, Schuster SM: Incorporation of monoclonal antibodies into cells by osmotic permeabilization: effect on cellular metabolism. J Biol Chem 1989;264:8214-8221.

- 30 Muanprasat C, Sonawane ND, Salinas D, Taddei A, Galietta LJ, Verkman AS: Discovery of glycine hydrazide pore-occluding CFTR inhibitors: mechanism, structure-activity analysis, and in vivo efficacy. J Gen Physiol 2004; 124:125-137.

- 31 Ma T, Thiagarajah JR, Yang H, Sonawane ND, Folli C, Galietta LJ, Verkman AS: Thiazolidinone CFTR inhibitor identified by high-throughput screening blocks cholera toxin-induced intestinal fluid secretion. J Clin Invest 2002;110:1651-1658.

- 32 Ma T, Vetrivel L, Yang H, Pedemonte N, Zegarra-Moran O, Galietta LJ, Verkman AS: High-affinity activators of cystic fibro- sis transmembrane conductance regulator (CFTR) chloride conductance identified by high-throughput screening. J Biol Chem 2002;277:37235-37241.

33 Flezar M, Heisler S: P2-purinergic receptors in human breast tumor cells: coupling of intracellular calcium signaling to anion secretion. J Pharmacol Exp Ther 1993;265:14991510.

34 Thomas NK, Brown TJ: ABC transporters do not contribute to extracellular translocation of hyaluronan in human breast cancer in vitro. Exp Cell Res 2010;316:1241-1251.

35 Auvinen P, Tammi R, Parkkinen J, Tammi M, Agren U, Johansson R, Hirvikoski P, Eskelinen M, Kosma VM: Hyaluronan in peritumoral stroma and malignant cells associates with breast cancer spreading and predicts survival. Am J Pathol 2000;156: 529-536.

36 Abraham EH, Vos P, Kahn J, Grubman SA, Jefferson DM, Ding I, Okunieff P: Cystic fibrosis hetero- and homozygosity is associated with inhibition of breast cancer growth. Nat Med 1996;2:593-596.

- 37 Li Y, Li L, Brown TJ, Heldin P: Silencing of hyaluronan synthase 2 suppresses the malignant phenotype of invasive breast cancer cells. Int J Cancer 2007;120:2557-2567.

38 Nickel V, Prehm S, Lansing M, Mausolf A, Podbielski A, Deutscher J, Prehm P: An ectoprotein kinase of group C streptococci binds hyaluronan and regulates capsule formation. J Biol Chem 1998;273:23668-23673.

- 39 Linsdell P, Hanrahan JW: Adenosine triphosphate-dependent asymmetry of anion permeation in the cystic fibrosis transmembrane conductance regulator chloride channel. J Gen Physiol 1998;111:601-614.

40 Lieb T, Forteza R, Salathe M: Hyaluronic acid in cultured ovine tracheal cells and its effect on ciliary beat frequency in vitro. J Aerosol Med 2000;13:231-237.

41 Manzanares D, Monzon ME, Savani RC, Salathe M: Apical oxidative hyaluronan degradation stimulates airway ciliary beating via RHAMM and RON. Am J Respir Cell Mol Biol 2007;37:160-168.

42 Wu R, Wu MM: Effects of retinoids on human bronchial epithelial cells: differential regulation of hyaluronate synthesis and keratin protein synthesis. J Cell Physiol 1986; 127:73-82.

43 Paul A, Picard J, Mergey M, Veissiere D, Finkbeiner WE, Basbaum CB: Glycoconjugates secreted by bovine tracheal serous cells in culture. Arch Biochem Biophys 1988;260: 75-84.

44 Monzon ME, Casalino-Matsuda SM, Forteza RM: Identification of glycosaminoglycans in human airway secretions. Am J Respir Cell Mol Biol 2006;34:141.

-45 Baraniuk JN, Shizari T, Sabol M, Ali M, Underhill CB: Hyaluronan is exocytosed from serous, but not mucous cells, of human nasal and tracheobronchial submucosal glands. J Invest Med 1996;44:47-52.
46 Engelhardt JF, Yankaskas JR, Ernst SA, Yang Y, Marino CR, Boucher RC, Cohn JA, Wilson JM: Submucosal glands are the predominant site of CFTR expression in the human bronchus. Nat Genet 1992;2:240-248.

47 Doucet L, Mendes F, Montier T, Delepine P, Penque D, Ferec C, Amaral MD: Applicability of different antibodies for the immunohistochemical localization of CFTR in respiratory and intestinal tissues of human and murine origin. J Histochem Cytochem 2003; 51:1191-1199.

-48 Regnier A, Dannhoffer L, Blouquit-Laye S, Bakari M, Naline E, Chinet T: Expression of cystic fibrosis transmembrane conductance regulator in the human distal lung. Hum Pathol 2007;39:368-376.

49 Mergey M, Lemnaouar M, Veissiere D, Perricaudet M, Gruenert DC, Picard J, Capeau J, Brahimi-Horn MC, Paul A: CFTR gene transfer corrects defective glycoconjugate secretion in human CF epithelial tracheal cells. Am J Physiol 1995;269:L855-L864.

50 Tufvesson E, Aronsson D, Bjermer L: Cysteinyl-leukotriene levels in sputum differentiate asthma from rhinitis patients with or without bronchial hyperresponsiveness. Clin Exp Allergy 2007;37:1067-1073.

-51 Dentener MA, Vernooy JH, Hendriks S, Wouters EF: Enhanced levels of hyaluronan in lungs of patients with COPD: relationship with lung function and local inflammation. Thorax 2005;60:114-119.

52 Sahu SC, Ulsamer AG: Hyaluronic acid: an indicator of pulmonary injury? Toxicol Lett 1980;5:283-286.

53 Vasconcellos CA, Allen PG, Wohl ME, Drazen JM, Janmey PA, Stossel TP: Reduction in viscosity of cystic fibrosis sputum in vitro by gelsolin. Science 1994;263:969-971.

54 Lethem MI, James SL, Marriott C, Burke JF: The origin of DNA associated with mucus glycoproteins in cystic fibrosis sputum. Eur Respir J 1990;3:19-23.

55 Teichgraber V, Ulrich M, Endlich N, Riethmuller J, Wilker B, De Oliveira-Munding CC, van Heeckeren AM, Barr ML, von Kürthy G, Schmid KW, Weller M, Tummler B, Lang F, Grassme H, Doring G, Gulbins E: Ceramide accumulation mediates inflammation, cell death and infection susceptibility in cystic fibrosis. Nat Med 2008; 14:382391.

56 Leigh MW, Kylander JE, Yankaskas JR, Boucher RC: Cell proliferation in bronchial epithelium and submucosal glands of cystic fibrosis patients. Am J Respir Cell Mol Biol 1995; 12:605-612.

57 Okada Y, Maeno E, Mori S: Anion channel involved in induction of apoptosis and necrosis. Adv Exp Med Biol 2004;559:205-209.

58 Guggino WB: Cystic fibrosis and the salt controversy. Cell 1999;96:607-610.

59 Day AJ, De La Motte CA: Hyaluronan cross-linking: a protective mechanism in inflammation? Trends Immunol 2005;26: 637-643. 